\title{
Participation of the Attorney in Civil Cases Regarding the Assignment of Responsibility in the Form of Losses
}

\author{
Koval V.N. ${ }^{1, *}$ Monastyrsky Yu.E. ${ }^{2}$ \\ ${ }^{I}$ The Ministry of Science and Higher Education of the Russian Federation, Moscow, Russia \\ ${ }^{2}$ Moscow State Institute of International Relations (MGIMO), Moscow, Russia \\ *Corresponding author. Email: v.n.koval@sevsu.ru
}

\begin{abstract}
The concept of responsibility is a key concept in the civil law science. Its universal meaning lies in the monetization of other people's negative property consequences and the assignment of their financial results to the involved person. At the dawn of human society, responsibility consisted of a reaction to non-compliance with legal requirements and acted in the form of an imposed fine which was multiple of the cost of loss. As far as society was developing, the monetary repression had already been classified into civil and criminal law, into response to personal insult and failure to fulfill property obligations (contractual and non-contractual). At the same time, the forfeit did not always ensure the recovering of the financial condition, and on the other hand, on the contrary, it created the abuse prerequisites. Another way to protect subjective rights became widely used, this is a way of losses recovery. The legal category of lost profits, as an important component of losses, became a part of professional life. The mechanism for the development of the said instrument was included in the legislation, since it was also defined as "future expenses for the recovery of the violated right". Unfortunately, trial participants don't use this instrument actively, and judges do not yet perceive such a broad understanding of possible losses. The participation of a professional defender becomes a determining factor in the effectiveness of demands for compensation.
\end{abstract}

Keywords: recovery of losses, liability, civil law, advocate, status

\section{INTRODUCTION}

The aim of this study is to draw attention to the main type of property liability. The developing economic turnover, while providing reproduction and augmentation of material wealth, requires adequate legal mechanisms and means of regulation from the legislator, courts, and juridical science. The use of the full range of opportunities provided by the legislation still depends on the quality of legal support, the relevance and effectiveness of legal practices, primarily to recover the violated legal civil rights. It is based on unfulfilled individual commercial (household and other) expectations enclosed in each case in a stimulating legal shell (property rights, etc.) and having a real possibility of judicial protection.

Among the means of protection, the fundamental role belongs to losses recovery. At the same time, the potential of this universal legal instrument is not entirely used by legal professionals for a number of reasons. At first sight, the concept of losses can be considered unconventional for the continental legal system. The recovering function of civil law is understood within its framework, first of all, as the performance of what is actually due, i.e., in the form it arose because of legal facts.

Meanwhile, in a dynamic legal and commercial environment, an obligation ignored by the respondent often no longer bring significant value to the person affected. For these cases, only monetary satisfaction is suitable as the only acceptable way of compensating for lost property or replacing unobtained material wealth.

The other side of the access to justice aimed at a civilized resolution of a gigantic amount of economic conflict is sometimes overloaded courts. Therefore, the size of claims filed and satisfied in monetary form is often reduced in order to eliminate the incentive to enrich through court processes. The first person who is able to restrain such a development is a trained advocate.

The essence of the economic turnover means that losses recovery in post-industrial countries becomes the main method for protecting the legal civil rights. At the same time, the dispute settlement bodies cannot cope with its use and in some cases they either refuse a suit or, as it was mentioned, reduce the amount claimed for various reasons. The lack of doctrinal investigation of the place for satisfaction of claims for losses in the system of individual rights protecting which serves the main purpose of legal regulation, namely, the recovery of property status, also makes itself felt. 


\section{METHODS}

The methodological basis of the study was made up of private scientific (special legal, comparative legal) and general scientific (task-theoretical, teleological and system) methods of analysis. The task-theoretical approach is applied when considering fundamental issues. The private scientific method of comparative legal analysis is used to highlight the features of different claims for losses and representation. The teleological method contributed to the establishment of present and future regulatory purposes. In the process of studying and comprehending specific legal issues, the general logical methods were used (abstraction, analysis, synthesis, analogy, generalization, and so on).

\section{RESULTS}

Summarizing the existing knowledge, this publication made it possible to formulate the concept of legal regulation of relations in the field of supporting the protection of legal rights, and, in particular, losses. The conclusion can form the basis for further doctrinal research in this area in the framework of the formation of the modern theory of losses compensation and representation in relevant cases.

\section{DISPUTATION}

Losses recovery is a developing main civil legal institution, always attracting the attention of an academic audience around the world. Recently, it has acquired special significance, and its particular sides have become entire areas of scientific discussion. The topic of this study is disclosed in detail for the first time as a separate issue of adjudgment the losses incurred and the role of legal assistance. We hope this will facilitate further discussion of the ideas raised and conclusions reached in the civil law doctrine of the countries of the continental and AngloSaxon legal systems.

\section{DISCUSSION}

In processes with claims for damages, the preparation of materials and representation are carried out by professional advocates with attorney's status. Their written authority should contain the possibility of changing the requirements, its recall, its recognition, as well as the signing of an arbitration clause which should be specifically indicated in the power of attorney.

The advocacy is based on the principles of self-regulation, while it presents increased requirements for its members, which is not typical for the communities of auditors, appraisers, notaries and so on. This consists in standards that dictate the support of a professional level, honesty, and the highest conscientiousness in upholding the interests of their clients on the basis of unconditional and full compliance with the law. This is assigned in clause 1 and clause 2 of Art. 3 of the Federal Law dated May 31, 2002 No. 63-FZ "On Advocacy and the Bar association in the Russian Federation". "The Bar association is a civil society institution based on the principles of selfregulation." Its purpose is to maintain and implement rather high requirements for its members regarding preparation for the profession and the ban on combining advocacy with any other activity, etc. This is included primarily in the Code of Professional Ethics of Advocates (hereinafter - the "Code"). Interestingly, the Code takes precedence over the law in some matters, although it is not even a normative act, but a set of rules of conduct for members of a "corporation" of less legal force.

Although being of lower legal hierarchy, the Code has priority in a number of special issues over the law in the sense that it (the law) does not extend some general permissions to advocates.

According to Art. 978 of $\mathrm{CC}$ representative is always entitled to withdraw from the contract and terminate relations with the represented one. The same discretion is entrusted, as a general rule, to other participants in property relations, service providers for a fee (Article 782 of the Civil Code of the Russian Federation). However, the Code (Article 9) prohibits acting contrary to the interests of principals. The Article 6 establishes the inadmissibility of the waiver of defense. In our opinion, it should be interpreted broadly as extending not only to representation in criminal cases. We believe that chapter 10 of the Civil Code of the Russian Federation on representation is not applicable to the contract with advocates, although from the point of view of a judge, a advocate is a representative under power of attorney in civil cases, unlike criminal trials.

A person authorized by power of attorney with or without status can carry out significant legal actions: state claims, sign statements, etc. Most commentators also believe that the assistance of a defender falls under the regulation of Chapter 39 of CC "Compensated Rendering of Services". There are relevant cases that are not yet generalized by the highest court due to their small number, which is easy to understand. Decent advocates will not sue their clients, but in these processes the courts nevertheless applied the rules on services. However, we believe that this is incorrect. Fortunately, the courts, having no guidance, have not yet begun to apply the law on consumer protection to our advocacy. If this happened, the advocacy would have disappeared.

The meaning of the norms of the chapter at first glance suits legal assistance: according to Art. 779 of the Civil Code of the Russian Federation, the customer gives the task to the service provider and indicates the civil nature of the relationship (Article 9 of the Code). The Code also uses the term "services" as revealing the concept of "legal assistance".

The main reason why the application of the chapter on the provision of services for a fee is fatal for the market, or for the institution of advocate assistance, is the following: the paragraph 2 of Art. 782 of the Civil Code states that the 
contractor, in case of refusal to fulfil obligations under the contract, is obliged to compensate the customer for losses. If we project this on the relationship between the advocate and the client, it turns out that since the norm is imperative, whatever it is, the withdrawal from the contract (and the situation can be different) may be due to the statement of claim for losses by the client, which, as we know, includes lost profit. Thus, it is important to note that neither the chapter on representation, nor on the provision of services for the advocate-client relationship should be applicable.

At the same time, if we assume that the advocate is actually a legal representative, and the Civil Code extends its rules to these relations, we see that none of the three types of representation is also suitable for providing legal assistance. The commission is unsuitable because the commission agent has the conclusion of transactions on his own behalf as the main goal, with 3 people or on behalf of clients. The contract representative basically signs the contracts, transferring the legal consequences to the represented person or to the principal. This does not correspond to the essence of legal assistance. Non-legal actions are the main subject of the contract with the client, namely actual ones. They constitute the purpose of the agency contract, and we affirm that if the chapter on representation is valid, then in the future, the rules on agency should be applied to the attorney-client relationship.

At the same time, it is in the interest of our colleagues and the entire legal community to say that an agreement to provide the legal assistance in a claim for losses is a sui generis agreement, and this allows us to use Art. 421 of the Civil Code of the Russian Federation, therefore, our recommendation is that this is expressly stated and fixed in the contract with clients, and that it stipulates (under certain conditions or at the discretion of the legal defense attorney) the termination of the relationship unilaterally without consequences of losses recovery, if there was no significant violation of obligations.

Further, we would like to dwell on the advantages and disadvantages of the advocate's status in the representation for the support of claims for losses. The Code places some restrictions on advocate. It prohibits accepting orders that appear to be illegal and unlawful. An advocate cannot afford manipulation of evidence under the threat of disciplinary action. Let me remind you that this term is much broader than the concept of "falsification", which is now the procedural rights institution. In the truest sense of the word, falsification means "forgery", the production of written, other material evidence, signatures, while the manipulation of evidence can occur, for example, in the preparation of documents retroactively, which often happens when proving the so-called specific losses about the fact that some delay of the defendant has entailed, or will entail the payment of damages by virtue of Art. 15 of the Civil Code in view of the conclusion of the contract of plaintiff and subcontractor. Can this be considered as a falsification of evidence? In our opinion, no, but a simple representative does it, and we came across this, while the advocate is prohibited to do it (of course).
Let's move on to the dignity of the law profession. Firstly, its advantage is the ability to make requests, for the failure of which administrative responsibility is now provided. In a loss case, the value of requests is difficult to overestimate. We often face the competition of evidence in the process when we provide some information, for example, about prices, etc., which differ. The information provided by the state body at the advocate's request has a much greater procedural weight than the document or certificate provided by the other party.

Further, the advantage of an advocate is that he or she is restrained and stimulated by his or her reputation, which is also the reputation of his company. An advocate cannot afford poor quality, as he or she risks the market position of his or her advocate association. An advocate, unlike an ordinary citizen, is liable for ethical negligence even with the slightest negligence, while an ordinary citizen representative is only responsible for gross negligence. The advocate is obliged to store information received not only from the client, but also about the whole case in the strictest sense of the word. Advocate secrecy provides a much higher level of protection of information than ordinary commercial secrecy. A person having access to commercial secrecy can nevertheless, for example, mention this and even appear on television while an advocate cannot (without violating ethics for example), give interviews on unfinished business and do otherwise without the permission of the client.

The next advantage of the legal profession is the opportunity to complain about a violation of ethics by the advocate of the opposing party or other participants in the process. And such cases are heard and considered. The very possibility of such an action disciplines the parties. Thus, the process of losses with the participation of an advocate takes place at a higher level, the arguments are heard more thoroughly, and the parties behave more lawabiding.

Now let's move to the usual representation in cases of losses. The regulation provides that if the representative office is carried out by an ordinary person, although he or she has received a law degree or an organization whose charter provides for the provision of legal services, then there is usually evidence that does not fall into sight and is not analyzed by the legal community. Firstly, usually the structure that provides legal services is subject to the rules on the provision of paid services. So, these articles require their provision personally (Article 980 of the Civil Code of the Russian Federation), while in practice the following occurs: some LLC providing services hires a freelance person, and the client issues a power of attorney to him or her, but the contract is concluded by the organization. This is a significant violation of the contract for the provision of services, and the client may terminate it and recover losses.

The same organization, if it provides services to an entrepreneurial legal entity or business company, bears innocent liability, and the promises that are stated in the contract, but are not fulfilled due to force majeure, must entail full recovery of losses. We would like to draw attention to the fact that in the most important losses cases 
- Available at: https://ssrn.com/abstract=1098869 Access date - 01.02.2020.

abiding use of it is necessary and is an important component of effective legal and procedural protection.

\section{CONCLUSION}

The stimulation of litigants who are suing for losses helps to strengthen the culture of dispute settlement, for which the professional argumentation prepared by the advocate and the legal justification of the positions play the most important role. This will result in the accumulation of further legal material in the form of published litigation practice, which will be even wider and which can be used more enthusiastically in science during the scientific exchange of opinions, which will lead to the release of even more publications, their content and quality in presenting the problematic issues of recovery.

Particular attention to representation on claims for compensation for damages and lost profits will result in tangible procedural savings, since usually large disputes are accompanied by many claims of the parties involved, while a losses case, even one, can, in essence, combine and replace them since the financial results of the relationship between the parties are summarized here. Although such cases are more extensional they absorb all controversial issues, such as: the legal force of the disputed transactions, counterclaims, the price of violation, etc., it analyzes the most important issues of guilt, regardless of whether it is commercial or not, for example, the relations of the parties to the conflict are simply corporate.

The institution of losses compensation is top priority to all civil law and urgently requires development and improvement.

\section{REFERENCES}

[1] Federal Law dated May 31, 2002 No. 63-FZ "On Advocacy and the Bar association in the Russian Federation)) // www .: pravo.gov.ru.

[2] P. Benjamin, Penalties, Liquidated Damages and Penal Clauses in Commercial Contract: A Comparative Study of English and Continental Law (1960) 9 ICLQ 600 .

[3] M. Bussani, V.V. Palmer, The notion of pure economic loss and its setting // Pure economic loss in Europe, Cambridge: Cambridge University Press, 2003. [e-source]

http://catdir.loc.gov/catdir/samples/cam041/200203134 5.pdf - access date: 02.02.2020.

[4] Martijn W Hesselink, The Principles of European Contract Law: Some Choices Made by the Lando Commission (December 11, 2001). Global Jurist Frontiers, Vol. 1, No. 1, Article 4. [electronic resource].
[5] Ingeborg Schwenzer, Force majeure and hardship in international sales contracts. Victoria University of Wellington Law Review, 39, 2009.

[6] Abova T. E. The regulation on contractual freedom remains fundamental for all our law of obligations / $\mathrm{T}$. E. Abova, Reporter of the Arbitration Court of the Moscow District, No. 2, 2017.

[7] E. V. Gavrilov, The legacy of the practice of the Supreme Arbitration Court of the Russian Federation and the latest practice of the Supreme Court of the Russian Federation on compensation for intangible (reputation) harm to legal entities, Arbitration disputes, No. 4, 2017.

[8] V. Gruzdev Problems of losses recovery/ V. Gruzdev, Economy and Law, No. 1, 2011.

[9] E. K. Moiseev Legal services market reform in Russia: sociological analysis, No. 7, Law, 2017.

[10]Z. A. Papulova, Lawyer's request: problems of effective implementation, Law practice, No. 4, 2017. 